\title{
Hotel Attributes Influencing International Tourists' Satisfaction and Loyalty
}

\author{
Rojan Baniya* \\ Prajwal Thapa ${ }^{\star *}$
}

\begin{abstract}
This study investigates the influence of hotel attributes on satisfaction of 119 international tourists visiting to Nepal. It further analyzes the effect of satisfaction from hotels on revisit intention and recommendations by international tourists.119international tourists visiting to Nepal participated in the study. Correlation and multiple regression analyses were conducted to test hypotheses. Our result shows that among various hotel attributes, service quality and room \& front desks plays significant role in satisfaction of international tourists. The other attributes like security, business facility, value, food and recreation and security were found to be insignificant. Furthermore, satisfaction was found to be significant predictor of both attitudinal loyalty i.e. intentional loyalty and behavioral loyalty i.e. revisit intention. There are lots of practical and research implications of the findings like it's a lesson for Nepal Tourism Board, Hotel Association Of Nepal and other related stakeholders. It guides them as where to focus their energy in terms of generating satisfaction and loyalty from international tourists in case of hotel service.
\end{abstract}

Keywords: Hotel, Attributes, International, Tourists, Satisfaction, Loyalty, Purchase Intention, Revisit Intention.

\section{Introduction}

The importance of tourism to Nepal is unquestionably high as a key industry, up to the level that it can be considered third prominent religion in Nepal following Hinduism and Buddhism (Thapa, 2004). Nepal is witnessing increase in both international and domestic tourism in recent development. Gifted with an unmatched combination of natural, cultural and historical attractions, Nepal has been one of the common tourist destinations in the global tourist market and has been proposing distinctive tourist

* Rojan Baniya is Assistant Professor, Kathmandu University School of Management. Email: rojan@kusom.edu.np

** Prajwal Thapa is associated with Kathmandu University, School of Management. 
activities like mountaineering, adventure and soft trekking and cultural tours, jungle safari, wilderness trek and other various sports and adventure tourist undertakings (Sedai, 2013). Given the increase in international visitors and heightened interest in domestic tourism, Nepal holds the enormous potential to expand this sector to generate more income, employment etc. The government of Nepal rely on tourists' arrival to deal with its badly needed foreign exchange, and in due course hopes to generate more income, employment, and tax revenues (Thapa, 2004).

There is plethora of literatures that present tourism as a realistic economic option for local community development. However, literature fails to portray specific roles of tourist hotels to local communities' development, which in fact is the core element for promoting a feasible tourism industry in a destination (Muganda et al., 2010). Even though, the inclusion of local community in tourism development is considered significant, yet their role is equivocal. According to Godfrey \& Clarke (2000) the local inhabitants form a basic foundation in modern tourism, as they play pivotal role for the supply of accommodation, catering, information, transport facilities and services. Following this, in the second half of the twentieth century, the world witnessed emergence of whole service sector like hotels, lodges, and rest houses as a major source of employment amidst decline of the industries (Cole, 2006).

The ripple effect of this was world evolution of other service sectors and companies, including railways, shipping, airlines and banking (Blake et al., 2008). Particularly, published research illustrates hotel industries have long history of development from 43 A.D to the early 21st century (Kisembo, 2008). In the case of developed countries hotel industries have become an important economic sector with growth as predicted earlier by the International Monetary Fund. However, developing countries witnessed unevenly distributed growth (6.4 and $2.2 \%$ ) in advanced nations during 2010 (Ateljevic et al., 2008). All these indicated to the fact that hotels and restaurant are one of the sources of economic growth and can be considered pillars of tourism.

The tourism industry in Nepal has been prospering and blooming predominantly due to its unmatched and second to none tourist attractions regardless of having very basic and even scanty accommodation, accessibility and other ancillary facilities and services (Sedai, 2013).This indicates tourism in Nepal is mainly due to its richness in nature, culture and heritage, but the infrastructural arrangement has not paced up to meet the requirements. Referring back to the history, the conventional growth of accommodation facilities in Nepal commenced with the establishment of 'Royal Hotel' by a Russian national, Mr Boris Lissanevitch, in February 1955 (Satyal, 2004). However, in 1956 with the starting of the first five-year plan (1956-1961 AD) and following establishment of Tourist Development Board in 1957 under the Department of Industry (DoI), the real planned development and growth of tourism started in Nepal (Sedai, 2013). 
As touristic places become more popular, businesses try to cash in by offering various services in those areas creating crowd, and thus the excessive supply of these services ensures service provider face unparalleled competitive challenges. Accommodation is one of the important requirements during travel. Thus in highly competitive hotel industry, only those hoteliers with clear idea about guests' needs will survive and prosper. Dolnicar and Otter (2003) states that due to the high costs that are typically involved with investments in the hotel industry, it makes a lot of sense to study, which product components travelers appreciate. In addition to their statement, this study also believes that an inclusive understanding of driving factors affecting tourists' accommodation selection is essential for determining hotel guest satisfaction.

Furthermore, understanding guests' needs above all necessitates an understanding of how they choose a hotel. Given that hotel choice behavior involves a decision process and choice criteria are central to the process. A plethora of past research investigated how customers have made decisions regarding hotel/resort selection. The purpose of this study is to identify the important factors of hotel/resort selection for international travelers of Nepal. In the highly competitive marketing environment in the hospitality industry, it is essential that companies understand consumers and their decision- making as they seek to gain a competitive advantage. Nepal offering its own distinct destination attributes, attracts all kind of international tourists, however there has never been any study to understand their choices of accommodation like hotels, resorts etc. and reasons behind them.

\section{Literature Review}

The consumer decision-making process (CDP) model stated that consumers undergo three stages before they elect to purchase a good or service: need identification, search for information and evaluation of alternatives (Blackwell, Miniard, \& Engel, 2006). In right sense, these three stages are recognized as a cognitive function, which lead consumers through the purchase decision. A topic of interest here is the tourist's decision at selecting accommodation, more specifically a hotel, which follows similar decision-making process.

While making best possible hotel development decision, it helps knowing about important traits or features that govern accommodation choice. Those hotels attributes which tourists care about are pivotal for any hotel operators to make best possible hotel offering decision. Hotel attributes play a big role in guests' minds while determining to choose accommodation options. Those hotels that offer favorable attributes are likely to fall in consideration set of customers, and performing even better in critical aspect will certainly win customer's mind and heart.

Customers get influence by some special elements in products and thus end up purchasing in corresponding to their needs and preferences. These hotel attributes 
can be either intangible or intangible, and tangible comprise of two main parts of hotel attributes (Chang \& Wong, 2005). Tangible characteristics or physical attributes for a hotel are those elements that can be seen such as price, the form of facilities, the location, the existence of choices, word of mouth communication, and advertising, a familiar name and past experience. Intangible for a hotel can be characteristics such as security, dependability, service quality, reputation and staff behavior.

\section{Hotels as Important Component in Tourism Sector}

A hotel can be understood as a place that provides accommodation, meals and refreshment for allocated periods of time for those who maybook their accommodation either in advance or on the premises. Hotel is defined in several ways: "A place which supplies board and lodging" or "A place for the entertainment of the travellers" (Bhatia, 2006). A hotel is an institution where travellers are provided lodging, meals and other services. Furthermore, a hotel is a fixed immobile installation that provides lots of amenities like television and facilities, room services, laundry services, shops, auto rentals, airline ticketing, reservation, and banking. It is an open and unique system where the tourist moves in, consumes the product and returns with an intangible product (Bhatia, 2006).

Tourism infrastructure is not fulfilled without consideration of accommodation, thus accommodation acts as a vital foundation to development of tourism. In fact, accommodation is responsible for creating feeling of home away from home to tourists. Coming to current context, hotel industry has become a sophisticated industry. The importance of accommodation, both traditional (hotel, motel) and supplementary (camps, youth hostels and so on) as stimulant to international tourism has been well acknowledged by The United Conference on International Travel and Tourism organized in 1963. Many countries have identified the vital role that accommodation industry play in developing their tourism, and they have come forward to coordinate their activities by placing big incentives and concessions to the hoteliers (Bhatia, 2006).

\section{Factors Determining Customer Selection/Satisfaction of Hotel}

In current scenario, anywhere hotel industry has advanced, there is tremendous competition going on. Like for any other industry, customer satisfaction for hotel industry is critical. And without a doubt, hotel attributes are important determinant of customer satisfaction. In this entry, there are many studies built on customer's views of various hotel attributes such as room quality, reputation of hotel, helpfulness of staff for evaluating hotel's performance (Cadotte \& Turgeon, 1988). Hotel attributes are indeed deciding factors. Similarly, Barsky \& Labagh (1992) conducted study unraveling satisfaction issue by asking respondents to judge the hotel performance based on different hotel features. Also, 21 various studies that took place during 1984 
to 2000 were reviewed focusing on hotel attributes by Dolnicar and Otter (2003). The study resulted in identifying 173 hotel attributes such as Image, Service, Price/Value, Hotel, Room, Food and Beverage, Security and others. Thus, various hotel attributes have emerged as important attributes.

In a number of research projects that had been conducted, Callan (1996) recapitulated that the standard of cleanliness was given the highest rating in the selection of accommodation by customers. Lockyer (2002) confirmed to this finding that cleanliness has high importance for customers. Furthermore, other researches have shown that being a hospitality industry, customer satisfaction is greatly influenced by, the quality of interpersonal interaction between the customer and the contact employee (Lovelock, 1996). In another study, Knutson (1988) and Cadotte and Turgeon (1988)identified that clean, comfortable, well-maintained rooms, convenient locations, a safe environment, prompt and courteous services are crucial components of customer satisfaction. In other study, it showed that customer satisfaction is affected by the availability of customer services (Berry and Parasuraman, 1991). These various studies depicts that tourists prefer various attributes without confirming to one single or similar features of accommodation facility.

Satisfaction is always measured as an outcome variables, which stands as an integral part of an attempt to improve product quality with ultimate goal of establishing and sustaining company's competitive advantage (Cravens et al., 1988; Garvin, 1991). This study intends to measure satisfaction and its determinants.

\section{Perceptions of hotel service and facilities}

In any tourism industry, it is evident that both business travelers and leisure travelers comprise major segments, which are served by hotels. To understand both their preferences and likings is critical to hotel's success. There had been numerous studies in the past that analyzed hotel selection behavior and related issues of both business travelers and leisure travelers. Taking into consideration Knutson's (1988) comprehensive study, both business and leisure travelers deemed friendly service, clean, comfortable, well maintained rooms, convenient locations, prompt and convenience service, safe and secure environment as the drivers of selecting hotel for the first time as well as for repeated visits.

The data collected from the members of American Hotel and Motel Association stated that helpful employees, cleanliness and neatness of establishment, quality of service and employee knowledge of service were critical considerations for guests (Cladotte\& Turgeon, 1988). In another study, Atkinson (1988) mentioned key attributes for the travelers were the cleanliness, security, value for money, courtesy and helpfulness of staff. Also, travelers significantly judge personal service, physical attractiveness, relaxation opportunities, service standard, appealing image, and value 
for money (Wilensky \& Buttle, 1988). In the study conducted among members and non members of frequent guest program, the result showed that the highest attention drawing factors form the travellers were convenience of location and overall services (Rivers et al.,1991). In another study, when travelers were asked to rate the importance of 57 hotel attributes critical in making hotel choice decisions, price and quality came at the top, followed by security and convenience location related attributes (Ananth et al.,1992). Furthermore, in Barsky and Labagh's (1992) study, employee attitudes, location and rooms stood out as the predominant ones to impact hotel selection decision of both business and leisure travelers.

In other studies of leisure travelers, Clow et al., (1994), Lewis (1984) and Marshall (1993), found that security, personal interactions and room rates were considered salient. In a different angle, according to Choi \& Chu (2001) staff service quality, room quality and value were the most impactful factors in determining travelers' overall satisfaction levels and their likelihood of returning to the same hotel. In another entry, Yavas \& Babkus (2005) found three attributes general amenities, core services and convenience dimensions to be important attributes creating impact on both business travelers and leisure travelers' hotel choice decisions. All these studies conducted in past showed both commonalities and differences among factors of tourists' choice of accommodation.

This study aims to explore importance of hotel attributes for international travelers in Nepal, and this can help improve management's understanding of customer needs, and which could ultimately lead to customer satisfaction and repeat businesses (Atkinson, 1988). The theory of consumer behavior states that both customer's buying behaviors and levels of satisfaction are influenced by the customer's background, characteristics, and external stimuli (Engel et al.,1990). Thus, this study will reveal the requirements of international tourists who are particularly visiting Nepal.

\section{Tourist satisfaction - intentional loyalty relationships}

There is positive relationship between satisfaction and loyalty. In past most studies agree that satisfaction with a tourist experience benefits positively to loyalty (Pritchard \& Howard, 1997; Oppermann, 2000; Alexandris et al., 2006; Yuksel, 2007; Chi \& Qu, 2008).Although satisfaction does not confirm loyalty among the customers, it is equally true that loyal customers are satisfied (Jones \& Sasser, 1995). This study also explores the relationship between satisfaction, intention to revisit and recommendation by international tourists about hotels.

Furthermore, satisfaction and loyalty are measured by two main things - one is revisit or by recommendation to other customers who can be family or friends that have potent of being future tourists.(Yoon \& Uysal, 2005).Past empirical research shows that tourist satisfaction leads to intention to revisit and recommendations to 
others (Yoon \& Uysal, 2005; San Martin et al., 2008). There are other varied effects

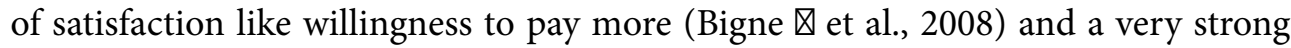
evidence of generating positive word of mouth (Macintosh, 2007).

Looking at these positive effects of satisfaction and loyalty, companies strive for attaining them. Thus, since, both satisfaction and loyalty are answers to longterm sustenance (Nicholls et al., 1998), and also are future desires of any tourism products and services (Gursoy et al., 2003, 2007), tourism business should always strive for it. Finally, several studies in the area of services show loyalty is the outcome of satisfaction (Mattila, 2001), and hotel business is no exception.

\section{Theoretical Framework And Research Hypotheses}

From numerous studies exploring hotel attributes responsible for satisfaction leading to intentional loyalty and intention to revisit, a theoretical model was developed.

The theoretical framework of the study is presented in Figure 1.

Independent Variables

Hotel Attributes

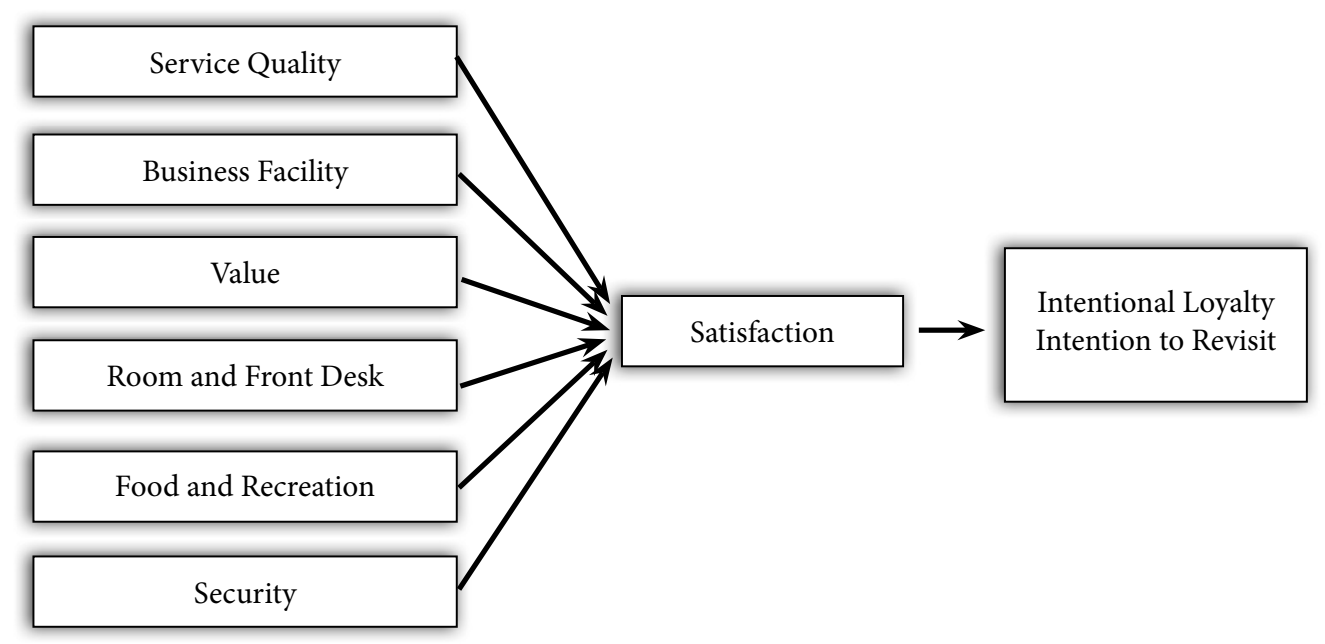

Figure 1: Theoretical Framework 


\section{Research Hypotheses}

This study proposed following hypotheses:

H1a: Service Quality is positively related to tourist satisfaction.

H1b: Business facility is positively related to tourist satisfaction.

H1c: Value is positively related to tourist satisfaction.

H1d: Room and Front Desk is positively related to tourist satisfaction.

H1e: Food and Recreation is positively related to tourist satisfaction.

H1f: Security is positively related to tourist satisfaction.

H2a: Tourist satisfaction is positively related to tourists' intentional loyalty.

$\mathrm{H} 2 \mathrm{~b}$ : Tourist satisfaction is positively related to tourists' intention to revisit.

\section{Method}

\section{Sample and procedure}

A self-administered survey questionnaire was created to relationship of various attributes of hotel with satisfaction and satisfaction with intentional loyalty and intention to revisit. The target population of thisstudy was international tourists visiting Nepal. The survey instrument was developed mainly with an aim to investigating the relationship between hotel attributes and tourist satisfaction, and tourist satisfaction and tourist loyalty. A convenience sampling approach was employed to collect data in October 2016 at different tourist locations but mainly focused in Pokhara, as Pokhara is main tourist destination within Nepal with high number of tourist inflow. Among 150self-administered questionnaires distributed, a total of 119 usable questionnaires were obtained representing $79 \%$ of response rate.

This study made use of a self-administered survey with four distinct parts gathering information on distinct travel characteristics and demographic variables of the international tourists, tourist's attitudes and perception of service quality of hotels, hotel attributes and tourists' satisfaction, intentional loyalty and revisit intention. The first part posed respondents' background; the demographic profiles included age, gender, nationality, income, occupation and nationality. In the second part, respondents were asked to express travel behavior like travel pattern and frequency, hotel booking methods. In the third part of the questionnaire, respondents were asked to indicate their agreement with statements describing the various attributes of the hotel. In the fourth part, respondents were asked to express their satisfaction, intentional loyalty and intention to revisit. The hotel attribute items, satisfaction, intentional loyalty and revisit intentions were assessed, using a 5-point Likert scale from $5=$ strongly agree to $1=$ strongly disagree. 
First, the findings were profiled by travel characteristics. Second, a scale reliability analysis using Cronbach's alpha was run to identify underlying internal consistency among the statement of constructs as they were borrowed from other studies. Thirdly, correlation and regression analysis were carried out to investigate the relationship between dependent and independent variables of the study. Cronbach's alpha was used to assess the reliability of each scale. The alpha coefficient of the scales ranged from .58 (FR) to .93 (IR).

\section{Results} below:

Before moving into the detailed analysis, the travel behavior is shown in table

Table 1:Travel Behavior

\begin{tabular}{|c|c|c|c|}
\hline Variable & $\%$ & Variable & $\%$ \\
\hline Who organized your travel? & & How did you book hotel? & \\
\hline Travel Agency & 4.2 & Hotel reservation/website & 9.2 \\
\hline Self & 84.0 & Online Travel Agents & 23.5 \\
\hline \multirow[t]{2}{*}{ Other } & 11.8 & Travel Agencies & 3.4 \\
\hline & & Others & \\
\hline $\begin{array}{l}\text { Have you ever visited online } \\
\text { booking sites for hotel such as } \\
\text { booking.com or tripadvisor. } \\
\text { com to compare hotels? }\end{array}$ & & $\begin{array}{l}\text { What asthe most important } \\
\text { source of information that } \\
\text { influenced in your decision } \\
\text { to chose th hotel? }\end{array}$ & \\
\hline Yes & 74.8 & Hotel reservation/website & \\
\hline \multirow[t]{2}{*}{ No } & 25.2 & Online information & 8.8 \\
\hline & & Travel Agencies & 17.2 \\
\hline $\begin{array}{l}\text { Have you ever booked a hotel } \\
\text { online? }\end{array}$ & & Television & .9 \\
\hline Yes & 73.9 & Magazine & .9 \\
\hline \multirow[t]{2}{*}{ No } & 26.1 & Friends/relatives & 37.7 \\
\hline & & Others & 24.6 \\
\hline \multicolumn{4}{|l|}{$\begin{array}{l}\text { What is the size of the group } \\
\text { you are travelling with } \\
\text { including yourself? }\end{array}$} \\
\hline 4 or less & 85.7 & & \\
\hline
\end{tabular}


$5-9$

10 or more

Approximately, how much you spend on residence during your trip?

Less than USD 1000

USD 1001 - 5000
10.9

3.4

Mean, standard deviation, Pearson correlation coefficients between study variables as well as their mean, standard deviation, and internal consistency reliability (Cronbach's alpha) are shown in the Table 2.

Table 2: Hotel Attributes, Satisfaction, Intentional Loyalty and Intention to Revisit - Mean, Standard Deviation, Correlation matrix, and Cronbach's alpha

\begin{tabular}{|c|c|c|c|c|c|c|c|c|c|c|c|c|}
\hline & & Mean & SD & 1 & 2 & 3 & 4 & 5 & 6 & 7 & 8 & 9 \\
\hline 1 & SQ & 4.05 & .52 & .75 & & & & & & & & \\
\hline 2 & $\mathrm{BF}$ & 2.74 & .94 & .15 & $\mathrm{n} / \mathrm{a}$ & & & & & & & \\
\hline 3 & $\mathrm{VL}$ & 4.00 & .49 & $.44^{\star \star}$ & $.26^{* *}$ & .61 & & & & & & \\
\hline 4 & RF & 4.01 & .55 & $.52^{\star *}$ & $.24^{* *}$ & $.61^{* *}$ & .66 & & & & & \\
\hline 5 & FR & 3.22 & .71 & $.24^{\star \star}$ & $.47^{\star *}$ & $.31^{\star *}$ & $.42^{\star *}$ & .58 & & & & \\
\hline 6 & SE & 3.64 & .99 & $.32^{\star *}$ & $.44^{\star *}$ & $.35^{\star *}$ & $.42^{\star *}$ & $.43^{\star *}$ & $. n / a$ & & & \\
\hline 7 & SF & 4.20 & .55 & $.52^{\star \star}$ & .06 & $.41^{\star *}$ & $.46^{\star *}$ & $.13^{\star *}$ & $.14^{\star *}$ & .80 & & \\
\hline 8 & IL & 4.12 & .65 & $.61^{\star *}$ & .08 & $.36^{* *}$ & $.48^{\star *}$ & $.23^{\star *}$ & $.21^{\star *}$ & $.76^{\star *}$ & .92 & \\
\hline 9 & IR & 3.63 & .92 & $.43^{\star *}$ & -.01 & $.29^{* *}$ & $.24^{\star}$ & .13 & .18 & $.43^{\star *}$ & $.55^{\star \star}$ & .93 \\
\hline
\end{tabular}

Note: ${ }^{\star \star} \mathrm{p}<.01,{ }^{\star} \mathrm{p}<.05$

SQ - Service Quality, BF - Business Facilities, VL - Value, RF - Room and Front desk, FR - Food and Recreation, SE - Security, SF - Satisfaction, IL Intentional Loyalty and IR - Intention to revisit

Cronbach's alpha shown in diagonal

The above result indicates most of the relationships between different study variables are significant and in the expected directions. 


\section{Building Predictive Models}

Table 3: Relationship between hotel attributes factors and tourist satisfaction with hotel

\begin{tabular}{|l|c|c|c|c|c|}
\hline Predictor Variable (Tourist Satisfaction) & $B$ & SE B & $\beta$ & $t$ & $p$ \\
\hline Constant & 1.948 & .450 & & 2.886 & .005 \\
\hline Service Quality & .415 & .103 & .394 & 4.014 & .000 \\
\hline Business Facility & -.031 & .061 & -.024 & -.239 & .811 \\
\hline Value & .164 & .144 & .127 & 1.142 & .256 \\
\hline Room \& Front Desk & .236 & .112 & .237 & 2.106 & .038 \\
\hline Food and Recreation & -.071 & .080 & -.092 & -.895 & .373 \\
Security & -.024 & .057 & -.014 & -.418 & .677 \\
\hline
\end{tabular}

Multiple regression analysis was used to test if the hotel attributes (namely, service quality, business facility, value, room and front desk, food and recreation and security) significantly predicted tourist satisfaction of hotel. The outcome of the regression analysis showed the five predictors elucidated $34.3 \%$ of the variance in tourist's satisfaction of hotel. $(\mathrm{R} 2=.343, \mathrm{~F}=8.5, \mathrm{p}<.01)$. It was found that service quality $(\beta=.39, \mathrm{p}<.01$ and friendly room $\&$ front desk $(\beta=.24, \mathrm{p}<.05)$ significantly predicted tourist's satisfaction of hotels, whereas business facility, value, food and recreation and security did not. The results show that the revisit intentions of international tourists' satisfaction with hotels has significant positive relationships with service quality and room and front desks, however there is no relationships between satisfaction and business facility, value, food recreation and security. This indicates that service quality and front desk and rooms are significant predictor of international tourist' hotel satisfaction.

Table 3: Relationship between Satisfaction and Intentional Loyalty

\begin{tabular}{|l|c|c|c|c|c|}
\hline $\begin{array}{l}\text { Predictor Variable } \\
\text { (Intentional Loyalty) }\end{array}$ & $\mathrm{B}$ & SE B & $\beta$ & $t$ & $p$ \\
\hline Constant & .448 & .308 & & 1.452 & .149 \\
\hline Satisfaction & .792 & .073 & .755 & 12.019 & .000 \\
\hline
\end{tabular}

Multiple regression analysis was used to test if tourist's satisfaction with hotel significantly predicted intentional loyalty of international tourist. The results of the regression indicated the satisfaction explained $57 \%$ of the variance $(\mathrm{R} 2=.570$, $\mathrm{F}=144.44, \mathrm{p}<.01)$. It was found that tourist's satisfaction with hotels significantly predicted intentional loyalty (i.e. word of mouth, recommendation etc.). The result shows that intentional loyalty for hotels among international tourists have significant 
positive relationships with satisfaction that they gain from the hotels. This indicates that satisfaction is significant predictor of international tourist' intentional loyalty.

Table 4: Relationship between Satisfaction and Revisit Intentions

\begin{tabular}{|l|c|c|c|c|c|}
\hline $\begin{array}{l}\text { Predictor Variable } \\
\text { (Revisit Intentions) }\end{array}$ & $\mathrm{B}$ & $\mathrm{SE} \mathrm{B}$ & $\beta$ & $t$ & $p$ \\
\hline Constant & .773 & .591 & & 1.309 & .193 \\
\hline Satisfaction & .683 & .140 & .425 & 4.876 & .000 \\
\hline
\end{tabular}

Multiple regression analysis was used to test if tourist's satisfaction significantly predicted international tourist' revisit intention to hotels. The results of the regression indicated the two predictors explained $18 \%$ of the variance ( $\mathrm{R} 2=.180, \mathrm{~F}=23.779$, $\mathrm{p}<.01)$. It was found that satisfaction significantly predicted revisit intentions $(\beta=$ $.425, \mathrm{p}<.01$ ). The result shows that revisit intention to a hotel has significant positive relationships with tourist's satisfaction from hotel. This indicates that tourist's satisfaction to hotel is significant predictor of international tourist' revisit intention to hotels.

\section{Discussion}

This study has grouped 18 hotel attributes into six hotel selection factors: Service Quality, Business Facilities, Value, Room and Front Desk, Food and Recreation, and Security. The main purpose of this study is to find how international tourists of Nepal evaluate the quality of different facets or attributes of a hotel, how satisfied they are with hotel, loyalty intention to revisit and willingness to recommend hotel to others. The study contributes to overall understanding of why international tourists choose a particular hotel and stay loyal to it.

In further analysis, the list of hotel attributes together predicted the satisfaction of international tourists with hotel, however only service quality and room and front desk were found to be significant. Conclusively, we could say that international tourists are motivated to stay in a hotel by its two main attributes i.e. service quality and room/front desk. The findings stand as a significant contribution to tourist hotel's satisfaction and loyalty studies. The results, which were devised on the basis of multiple regression analysis, show the imperative constituents with significant positive influence on the tourists' satisfaction, recommendations and revisit intention to hotels.

Undeviating from the previous studies that guest satisfaction is the highest priority for hotels competing with hundreds of others, and service quality is at the top of the travellers' list of the most important things when considering a hotel to stay in (Wipoosattaya, 2001), this study presents a congruent view. After 'service quality', 'room and front desk' was found to be the most important attribute in selecting a 
hotel and has the greatest impact on overall satisfaction, which is similar to previous studies (Choi \& Chu, 2001; Chu, 2002; Knutson, 1988; Tsai et al, 2011; Yavas \& Babakus, 2003). Service quality factor comprised of staff's behaviors like politeness and helpfulness, efficient services, neat appearances and multi-lingual skills. "Room cleanliness and comfort" is deemed to be the principal factor and is still important related to overall customer satisfaction (Chu, 2002; Dolnicar\& Otter, 2003; Lee, Han, \&Willson, 2011). This is similar to finding of the study, where room and front desk was chosen as significant predictor of hotel satisfaction. The room and front desk factor comprised of cleanliness, bed/mattress/pillow comfort, check-in/check-out and reservation.

Hence, destination managers and other tourism promoting bodies like Nepal Tourism Board should improve service quality and room and front desk of hotel, which impact satisfaction of international tourists. This is in consistence with the proposition that if customers are kept satisfied with the quality of service and amenities they received (in our case room and front desks), such satisfaction outcome may bolster and buttress their future repurchase intention and at the same time influence them to propagate favorable world of mouth publicity (Fornell, 1992; Halstead \& Page, 1992).In other research studies, it has been established that service quality convert intoa customer satisfaction, attraction of new customers, positive word-of-mouth, repeat visits, so forth (Akbaba, 2006; Reid \&Bojanic, 2009; Zabkar et al., 2009; Zeithaml et al., 2006). Yee et al. (2010) expressed that customer satisfaction is directly affected and has significant relationship with service quality, moreover the relationship between customer satisfaction and loyalty is also found to be highly significant. This finding of this study matches with previous findings.

\section{Implications}

Owing to the concept ofsatisfaction and loyalty, this study clearly exhibits that both attitudinal and behavioral loyalty towards a hotel is driven by satisfaction drawn from hotel attributes. When established hotel attributes that are institutedin hotelsin Nepal were examined from the eyes of the international tourists, two main attributes stood out - service quality and room \& front desk. These hotel attributes were the indispensable factors that lead to international tourist satisfaction and ultimately loyalty. In much clearer sense, once customers' preferences are clearly recognized and understood, hoteliers are in better position to predict and service their customer's needs and wants proactively, rather than being reactive to their dissatisfaction (Oberoi\& Hales, 1990). This study actually provides that guiding knowledge to manage international tourists' satisfaction and loyalty from hotels in Nepal.

In other words, it seems service quality and room \& front desksare the two main hotel attributes that are sought out by international tourists visiting Nepal, 
while choosing an accommodation. Consequently, the concerned authorities Nepal Tourism Board, Hotel Association of Nepal and other governing bodies, managers associated with various hotels within Nepal, universities and colleges teaching various hospitality related courses, processionals owning and working in hotel in Nepal should exhibit service quality and room \& front desk superiority performance that satisfies international tourists making stay in Nepal a worthy affair. If these two factors could be delivered, the study shows that tourists will be re-visiting these hotels and also will be generating positive words of mouth intensifying much needed loyalty and gain much needed competitive advantages.

\section{Limitations and Suggestions For Future Research}

This study has several limitations that need to be rectified in future research. First, there might be self-report bias due to the fact that all the study variables were captured from self-reported measures. Second, the samples for this study were drawn from mainly from Pokhara, which is top tourist destinations of Nepal, where international tourists could be found. Small sample size, drawn from one tourist destination might create doubt on the representativeness of the sample. Regardless, the findings of this study are in both in agreement and also in contrast with the findings of the studies carried out in the different cultural contexts suggesting that though satisfaction can be predicted by hotel attributes and loyalty can be predicted by satisfaction. Also replication of this study in Nepali cultural context to enhance the reliability of this study is suggested.

This study may be replicated with samples from all over Nepal in other tourist destinations so as to validate the findings of present study. Future studies could also examine the moderating role of other variables in the relationships between hotel attributes factors and international tourists' hotel satisfaction. With complete concentration on satisfaction and loyalty of international visitors, it is advised that future research investigate frequent domestic travelers to disclose factors that influence their hotel satisfaction and loyalty to promote the growing importance of domestic tourism nowadays.

\section{References}

Akbaba, A. (2006). Measuring service quality in the hotel industry: A study in a business hotel in Turkey. International Journal of Hospitality Management,25(2), 170-192.

Alexandris, K., Kouthouris, C., \& Meligdis, A. (2006). Increasing customers' loyalty in a skiing resort: The contribution of place attachment and service quality. International journal of contemporary hospitality management, 18(5), 414425. 
Ananth, M., DeMicco, F. J., Moreo, P. J., \& Howey, R. M. (1992).Marketplace lodging needs of mature travelers. The Cornell Hotel and Restaurant Administration Quarterly, 33(4), 12-24.

Ateljevic, I. (2008). Women empowerment through tourism. Wageningen University.

Atkinson, A. (1988). Answering the eternal question: what does the customer want?. The Cornell Hotel and Restaurant Administration Quarterly, 29(2), 12-13.

Barsky, J. D., \& Labagh, R. (1992). A strategy for customer satisfaction. The Cornell Hotel and Restaurant Administration Quarterly, 33(5), 32-40.

Berry, L. L., \& Parasuraman, A. (1991). Marketing service. Competing through Quality, New York.

Bhatia, A. K. (2006). International tourism management. Sterling Publishers Pvt. Ltd.

Blake, A., Arbache, J. S., Sinclair, M. T., \&Teles, V. (2008).Tourism and poverty relief. Annals of Tourism Research, 35(1), 107-126.

Cadotte, E. R., \& Turgeon, N. (1988). Key factors in guest satisfaction. Cornell Hotel and Restaurant Administration Quarterly, 28(4), 44-51.

Callan, R. J. (1996). An appraisement of UK business travelers' perceptions of important hotel attributes. Hospitality Research Journal, 19(4), 113-127.

Chang, E., \& Wong, S. (2005). Identifying and Exploiting Potentially Lucrative Niche Markets: the Case of Planned Impulse Travelers. Hong Kong Tourism SMEs, Service Quality and Destination Competitiveness, 295-311.

Chi, C. G. Q., \& Qu, H. (2008). Examining the structural relationships of destination image, tourist satisfaction and destination loyalty: An integrated approach. Tourism management, 29(4), 624-636.

Choi, T. Y., \& Chu, R. (2001). Determinants of hotel guests' satisfaction and repeat patronage in the Hong Kong hotel industry. International Journal of Hospitality Management, 20(3), 277-297.

Chow, K. E., Garretson, J. A., \& Kurtz, D. L. (1995). An exploratory study into the purchase decision process used by leisure travelers in hotel selection. Journal of Hospitality \& Leisure Marketing, 2(4), 53-72.

Chu, R. (2002). Stated-importance versus derived-importance customer satisfaction measurement. Journal of Services Marketing, 16(4), 285-301.

Cole, S. (2006). Cultural tourism, community participation and empowerment. Cultural tourism in a changing world: Politics, participation and (re) presentation, 89-103. 
Cravens, D. W., Holland, C. W., Lamb, C. W., \& Moncrief, W. C. (1988).Marketing's role in product and service quality. Industrial Marketing Management, 17(4), 285304.

Dolnicar, S., \& Otter, T. (2003). Which hotel attributes matter? A review of previous and a framework for future research.

Engle, J. F., Blackwell, R. D., \& Minuard, P. W. (1990). Consumer Behavior. 6th.

Engel, J. F., Miniard, P. W., \& Blackwell, R. D. (2006). Consumer behavior 10th Edition. Thomson South-Western. Mason. USA.

Enrique Bigné, J., Mattila, A. S., \&Andreu, L. (2008). The impact of experiential consumption cognitions and emotions on behavioral intentions. Journal of Services Marketing, 22(4), 303-315.

Fornell, C. (1992). A national customer satisfaction barometer: The Swedish experience. the Journal of Marketing, 6-21.

Garvin, D. A. (1991). How the Baldrige Award really works. Harvard Business Review, 69(6), 80-93.

Godfrey, K., \& Clarke, J. (2000). The tourism development handbook: a practical approach to planning and marketing. Thomson Learning.

Gursoy, D., McCleary, K. W., \& Lepsito, L. R. (2007). Propensity to complain: Effects of personality and behavioral factors. Journal of Hospitality \& Tourism Research, 31(3), 358-386.

Gursoy, D., McCleary, K. W., \& Lepsito, L. R. (2003). Segmenting dissatisfied restaurant customers based on their complaining response styles. Journal of food service business research, 6(1), 25-44.

Halstead, D., \& Page, T. J. (1992). The effects of satisfaction and complaining behavior on consumer repurchase intentions. Journal of Consumer Satisfaction, Dissatisfaction and Complaining Behavior, 5(1), 1-11.

Jones, T.O. \& Sasser, W.E. (1995). Why satisfied customers defect. Harvard Business Review, 73(6): 89-99.

Knutson, B. J. (1988). Frequent travelers: Making them happy and bringing them back. The Cornell Hotel and Restaurant Administration Quarterly, 29(1), 82-87.

Lee, M., Han, H., \& Willson, G. (2011).The role of expected outcomes in the formation of behavioral intentions in the green-hotel industry. Journal of Travel \& Tourism Marketing, 28(8), 840-855.

Lewis, R. C. (1984). The basis off hotel selection. Cornell hotel and restaurant administration quarterly, 25(1), 54-69. 
Lockyer, T. (2002). Business guests' accommodation selection: the view from both sides. International Journal of Contemporary Hospitality Management,14(6), 294300 .

Lovelock, C.H. (1996), Services Marketing, 3rd ed., Prentice Hall, Upper Saddle River, NJ.

Macintosh, G. (2007). Customer orientation, relationship quality, and relational benefits to the firm. Journal of Services Marketing, 21(3), 150-159.

Marshall, A. (1993). Safety top guest's priority list; sell security as No. 1 amenity. Hotel and Motel Management, 208(11), 21.

Mattila, A. S. (2001). The impact of relationship type on customer loyalty in a context of service failures. Journal of Service Research, 4(2), 91-101.

Muganda, M., Sahli, M., \& A Smith, K. (2010). Tourism's contribution to poverty alleviation: A community perspective from Tanzania. Development Southern Africa, 27(5), 629-646.

Nicholls, J. A. F., Gilbert, G. R., \&Roslow, S. (1998). Parsimonious measurement of customer satisfaction with personal service and the service setting. Journal of Consumer Marketing, 15(3), 239-253.

Oberoi, U., \& Hales, C. (1990). Assessing the quality of the conference hotel service product: towards an empirically based model. Service Industries Journal, 10(4), 700-721.

Oppermann, M. (2000). Tourism destination loyalty. Journal of travel research, 39(1), 78-84.

P. Kisembo, Consumer Lobby Pushes for Standards, Quality Laws, The Guardian (2008).

Pritchard, M. P., Howard, D. R., \& Havitz, M. E. (1992). Loyalty measurement: A critical examination and theoretical extension. Leisure Sciences, 14(2), 155-164.

Reid, R. D., \& Bojanic, D. C. (2009). Hospitality marketing management. John Wiley and Sons.

Rivers, M. J., Toh, R. S., \& Alaoui, M. (1991). Frequent-stayer programs: the demographic, behavioral, and attitudinal characteristics of hotel steady sleepers. Journal of Travel Research, 30(2), 41-45.

San Martin, H., Collado, J. \& Rodriguez, I. (2008). El proceso global de satisfaccionbajo multiples estandares de comparacion: el papelmoderador de la familiaridad, la involucracion y la interaccioncliente-servicio. Revista Espanola de Investigacionde Marketing ESIC, 12(1): 65-95. 
Satyal Y.R. (2004). Tourism in Nepal: A Profile. Adroit Publication. India.

Sedai, R. C. (2013). Tourist accommodation facilities in the major tourist areas of Nepal. Nepal Tourism and Development Review, 1(1), 102-123.

Thapa, B. (2004). Tourism in Nepal: Shangri-La's troubled times. Journal of Travel \& Tourism Marketing, 15(2-3), 117-138.

Tsai, H., Yeung, S., \& Yim, P. H. (2011). Hotel selection criteria used by mainland Chinese and foreign individual travelers to Hong Kong. International journal of hospitality \& tourism administration, 12(3), 252-267.

Wilensky, L., \& Buttle, F. (1988). A multivariate analysis of hotel benefit bundles and choice trade-offs. International Journal of Hospitality Management, 7(1), 29-41.

Wipoosattaya, W. (2015). Tourists' perceptions of hotel frontline employees' questionable job-related behavior.

Yavas, U., \& Babakus, E. (2005). Dimensions of hotel choice criteria: congruence between business and leisure travelers. International Journal of Hospitality Management, 24(3), 359-367.

Yee, R. W., Yeung, A. C., \& Cheng, T. E. (2010). An empirical study of employee loyalty, service quality and firm performance in the service industry.International Journal of Production Economics, 124(1), 109-120.

Yoon, Y., \& Uysal, M. (2005). An examination of the effects of motivation and satisfaction on destination loyalty: a structural model. Tourism management,26(1), 45-56.

Yüksel, A., \&Yüksel, F. (2007). Shopping risk perceptions: Effects on tourists' emotions, satisfaction and expressed loyalty intentions. Tourism management, 28(3), 703713.

Žabkar, V., Brenčič, M. M., \& Dmitrović, T. (2010). Modelling perceived quality, visitor satisfaction and behavioural intentions at the destination level. Tourism management, 31(4), 537-546.

Zeithaml, V. A., Bitner, M. J., \& Gremler, D. D. (2006). Services marketing: Integrating customer focus across the firm. 